\title{
Karyotype analysis of Aeluropus species (Poaceae)
}

\author{
M. Keshavarzi ${ }^{1,2 *}$, S. Mosaferi ${ }^{1,3}$, F. Abivardi ${ }^{1,4}$ \\ ${ }^{I}$ Department of Plant Sciences, Faculty of Biological Sciences, Alzahra University, Tehran, Iran \\ ${ }^{2}$ E-mail:m.keshavarzi@alzahra.ac.ir; ORCID iD: https://orcid.org/0000-0003-3032-9408 \\ ${ }^{3}$ E-mail: s.mosaferi@alzahra.ac.ir; ORCID iD: https://orcid.org/0000-0003-0501-6637 \\ ${ }^{4}$ E-mail: abivard11@yahoo.com \\ * Corresponding author
}

Keywords: Aeluropus, Chloridoideae, chromosome number, mitosis, population.

Summary. Aeluropus, a member of Poaceae subfam. Chloridoideae, includes six species, three of which occur in Iran. They are perennial halophytes of deserts and coastal marshlands of Iran. The genus is considered as a rich genetic source for gene manipulation and using it for crop improvement. Previous studies showed that members of Chloridoideae have small chromosomes and the base chromosome number $n=10$. There are few chromosome records for Aeluropus species. Somatic metaphases of seven populations of three Aeluropus species were studied. The first chromosome counts $(2 n=20)$ based on Iranian material for three species, A. macrostachyus, A. littoralis and A. lagopoides, are concordant with previous records outside Iran; mitotic number for A. macrostachyus is recorded here for the first time.

\section{Анализ кариотипа видов Aeluropus (Poaceae)}

\author{
М. Кешаварзи, С. Мосафери, Ф. Абиварди
}

Кафедра наук о растениях, факультет биологических наук, Университет Альзахра, г. Тегеран, Иран

Ключевые слова: Иран, митоз, популяция, число хромосом, Chloridoideae.

Аннотация. Род Aeluropus подсемейства Chloridoideae семейства Роасеае представлен тремя видами в Иране и шестью - в мире. Это многолетники, обитатели соленых болот и пустынь. Считается, что виды рода обладают ценными свойствами и являются перспективными объектами для генетических исследований и использования их для улучшения свойств сельскохозяйственных культур. Предыдущие работы показали, что представители трибы Cynodonteae обладают небольшими хромосомами и базовым числом $n=10$. Подсчётов хромосомных чисел для видов рода Aeluropus в литературе приводится немного. Нами изучены метафазные пластинки соматических хромосом у трех видов рода из семи популяций. Для A. macrostachyus, A. littoralis и A. lagopoides числа хромосом $2 n=20$ определены первый раз на материале из Ирана, при этом для спорофита A. macrostachyus оно указывается впервые.

\section{Introduction}

Aeluropus Trin. (Chloridoideae Kunth ex Beilschm., Cynodonteae Dumort., Poaceae Barnhart) includes three species in Iran and six in the world
(Bor, 1970; Watson et al., 1992; POWO, 2021). They are halophytic elements of central and tropical Asia, Africa, and Europe (Bor, 1970). Aeluropus littoralis (Gouan) Parl. as a perennial halophyte is native to the central desert and coastal marshlands 
of Iran. This species is considered as a rich genetic source for gene manipulation and crop improvement (Modarresi et al., 2012). Aeluropus lagopoides (L.) Trin. ex Thwaites is known as a salt-secreting, rhizomatous perennial halophyte distributed on dry and salty soils of Iran. This species survives in harsh environments due to the vigorous seed production, epicuticular wax layer, salt glands, and small leaves (Mohsenzadeh et al., 2006). Aeluropus macrostachyus Hack. is of potential fodder value in Southwest Asia (Öztürk et al., 2019). Due to the presence of hybrids, subspecies, and ecotypes in the studied taxa, Aeluropus identifications are somehow difficult (Abivardi et al., 2010).

Previous records indicated that members of Cynodonteae possess small chromosomes and the base chromosome number $n=10$. Tarnavschi and Lungeanu (1982) and Kožuharov and Petrova (1991) recorded $2 n=20$ for sporophyte of A. littoralis. Moreover, $2 n=30$ and $2 n=60$ were reported for this taxon (Tarnavschi, 1948; Matevosian, 1975).

In A. lagopoides, $2 n=20$ (Murin, Chaudhri, 1970; Nagabhushana, 1980) and $2 n=50$ (Baquar, Saeed, 1969) for sporophyte and $n=20$ (Moinuddin et al., 1994) for gametophyte have been recorded. Khatoon and Ali (1993) recorded $x=10$ for $A$. littoralis and A. macrostachyus. There are no records for the mitotic number of $A$. macrostachyus.

Variations in the species chromosomes provide useful data for biosystematic and breeding studies. In this project, the chromosome counts and karyotype parameters for the Iranian species of Aeluropus are studied for the first time.

\section{Material and methods}

In this project, 7 accessions of three Aeluropus species in Iran were gathered from nature (Table 1). Vouchers are deposited in the herbarium of Alzahra University (ALUH) and the herbarium of the Research Institute of Forests and Rangelands (TARI).

Table 1

Details of Aeluropus population and taxa studied

\begin{tabular}{lc}
\hline \multicolumn{1}{c}{ Locality, collector, voucher number } & \multicolumn{1}{c}{ Species } \\
\hline Azerbaijan, Tabriz to Ahar, Beside Salt Lake, Zare, Abivardi, 8511 (ALUH) & \\
Kerman, Jazmorian, Zehkelot, Khodashenas, 859 (ALUH) & \\
Markazi, Saveh, Keshavarzi, Abivardi, 8512 (ALUH) & \\
Semnan, Garmsar, Abivardi, 8513 (ALUH) & A. lagopoides \\
Qom, Qom, Foroughi, 1097 (TARI) & \\
Semnan, Touran Protected Region, Abbas Abad, Freitag, 14152 (TARI) & A. macrostachyus \\
\hline
\end{tabular}

The plants were collected during the years 2007-2017 in their natural habitats (Table 1). For the somatic chromosome study, the seeds were germinated on moist filter paper in the laboratory (ca. $21-24^{\circ} \mathrm{C}$ ). In order to vernalize seeds, they were put at $4{ }^{\circ} \mathrm{C}$ in a refrigerator $(48-72 \mathrm{~h})$, then transferred to room temperature. The growing root tips of ca. 0.7$1.0 \mathrm{~cm}$ long were cut and pre-treated in a saturated $0.002 \mathrm{M}$ water solution of 8 -hydroxyquinolin at $4^{\circ} \mathrm{C}$ in a refrigerator $(2-4 \mathrm{~h})$ and fixed in a cold mixture of ethanol and acetic acid ( $3: 1)$ for $24 \mathrm{~h}$. Root tips were macerated in two ways: 1) $1 \mathrm{~N} \mathrm{HCl}$ was used for 3 hours (Cold Hydrolysis) at room temperature; 2) Hot Hydrolysis was used by means of $1 \mathrm{~N} \mathrm{HCl}$ for $6 \mathrm{~min}$. in $60^{\circ} \mathrm{C}$ bath. Temporary slides were made by squashing the segments and staining in $2 \%$ acetoorcein for 30-45 min. Good metaphase plates were photographed with Olympus microscope equipped with DP12 digital camera and measured Ideokar software ver. 1.2.
Chromosomes were identified based on Levan et al. (1964). For karyotype symmetry, the coefficient of variation of chromosome length $\left(\mathrm{CV}_{\mathrm{CL}}\right)$ based on Paszko (2006) and mean centromeric asymmetry $\left(\mathrm{M}_{\mathrm{CA}}\right)$ based on Peruzzi and Eroğlu (2013) were determined. A2 index of Zarco (1986) and coefficient of variation of the chromosome size (CV) were also calculated.

\section{Results}

The chromosome counting in seven accessions of different species of Aeluropus in Iran showed only one ploidy level $(2 n=20)$. The best time to catch the highest somatic metaphases at root tips was $10 \mathrm{a} . \mathrm{m}$. to $01 \mathrm{p}$. m. in the species studied. The summary of karyotype features is shown in Table 2.

The size of the shortest chromosome varied from 0.54 to $0.91 \mu \mathrm{m}$ while the size of the longest varied from 1.19 to $1.67 \mu \mathrm{m}$. The range of total length of 
the haploid chromosome varied from 17.99 to 24.06 $\mu \mathrm{m}$. The highest value of chromosome size variation (CV) occurred in A. littoralis and the lowest one in A. lagopoides. The coefficient of variation of chromosome length $\left(\mathrm{CV}_{\mathrm{CL}}\right)$ was the highest in A. littoralis and the lowest in A. macrostachyus
Aeluropus littoralis and A. lagopoides showed 3B Stebbins' symmetry class while $A$. macrostachyus showed 3A. Aeluropus lagopoides and A. macrostachyus had metacentric chromosomes while $A$. littoralis had nine metacentric and one submetacentric chromosome (Figs. 1-3).

Table 2

Karyotype features of Aeluropus taxa studied

\begin{tabular}{cccccccccccl}
\hline $\mathrm{KF}$ & $\mathrm{ST}$ & $\mathrm{CV}$ & $\mathrm{M}_{\mathrm{CA}}$ & $\mathrm{CV}_{\mathrm{CI}}$ & $\mathrm{A} 2$ & $\mathrm{~L} / \mathrm{S}$ & $\mathrm{TL}$ & $\mathrm{S}$ & $\mathrm{L}$ & $2 \mathrm{n}$ & Species \\
\hline $10 \mathrm{~m}$ & 3B & 21 & 9.9 & 21.34 & 0.21 & 2.16 & 17.99 & 0.55 & 1.19 & 20 & A. lagopoides \\
$9 \mathrm{~m}+1 \mathrm{sm}$ & 3B & 26 & 13.7 & 26.25 & 0.26 & 2.72 & 19.41 & 0.54 & 1.47 & 20 & A. littoralis \\
$10 \mathrm{~m}$ & 3A & 20 & 8.99 & 19.72 & 0.20 & 1.83 & 24.06 & 0.91 & 1.67 & 20 & A. macrostachyus \\
\hline
\end{tabular}

Abbreviations: $\mathrm{TL}$ - total chromatin length $(\mu \mathrm{m}), \mathrm{L} / \mathrm{S}$ - ratio of the longest to shortest chromosome $(\mu \mathrm{m}), \mathrm{A} 2-$ inter-chromosomal asymmetry index (Zarco), $\mathrm{CV}_{\mathrm{CL}}$ - coefficient of variation of chromosome length, $\mathrm{M}_{\mathrm{CA}}-\mathrm{mean}$ centromeric asymmetry, CV - coefficient of variation, ST - Stebbins' symmetry class, KF - karyotypic formulae.

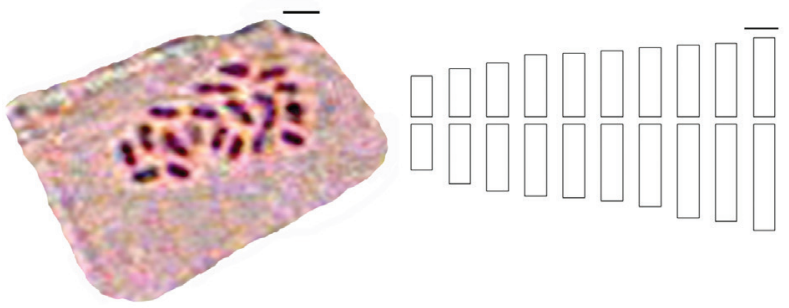

Fig. 1. Somatic metaphases in Aeluropus lagopoides in Iran $(2 \mathrm{n}=20)$ (Scale bar: $3 \mu \mathrm{m})$.
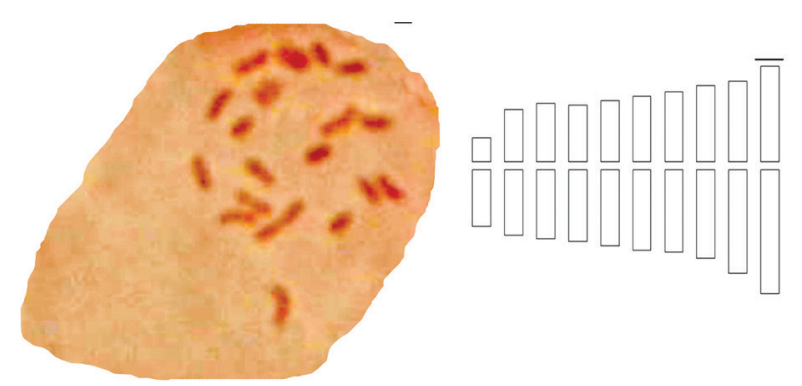

Fig. 2. Somatic metaphases of Aeluropus littoralis in Iran $(2 \mathrm{n}=20)($ Scale bar: $3 \mu \mathrm{m})$.

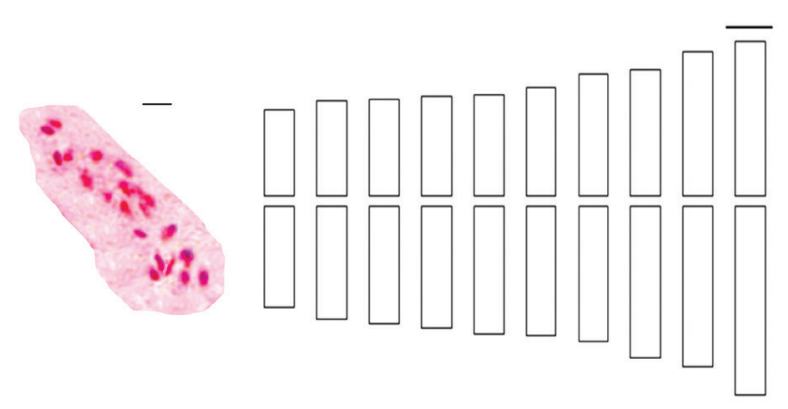

Fig. 3. Somatic metaphases of Aeluropus macrostachyus in Iran $(2 n=20)$ (Scale bar: $3 \mu \mathrm{m})$.

\section{Discussion}

Aeluropus and Odyssea Stapf are the members of subtribe Aeluropodinae P. M. Peterson of Eurasia and Africa origin (Soreng et al., 2015, 2017). Aeluropus is a small genus with three species in Iran. They are mainly found as members of halophytic vegetation. These species have very small chromosomes and the basic chromosome number $x=10$.

The most common basic chromosome numbers in Poaceae are $x=7,9,10,12$ (Stebbins, 1982). It is assumed that the original basic chromosome number for Poaceae species is $x=7$, and the larger ones are its derivatives. Another assumption is that the ancestral genome has $x=5$ that varied by duplications and inter-chromosomal translocations to provide an intermediate ancestral genome with $x=12$ (Shchapova, 2012).

Basic chromosome number is constant in some tribes of Poaceae. Two main and frequent basic chromosome numbers are $x=7(29.5 \%)$ and $x=$ $10(31.9 \%)$. Avdulov (1931) considered $x=12$ as the ancestral basic chromosome number that results in other basic chromosome numbers by reduction due to aneuploidy (Hilu, 2004), but others as Stebbins (1982) considered $x=6$ and 7 as ancestral in primitive genera and this discussion is still being continued (Hilu, 2004; Shchapova, 2012).

Chloridoideae has $x=9$ and 10 as the common basic numbers (Hilu, 2004); $x=9$ is found in $86 \%$ of the species and $x=10$ in $13 \%$ (de Wet, 1987). The basic chromosome number $x=5$ has not been reported for this subfamily. Hilu and Alice (2001) believed that $x=10$ is a plesiomorphic character in Chloridoideae. It is evident that aneuploid reduction 
from $x=12$ to $x=10$ and $x=9$ in some genera appeared in the early stages of the evolutionary history of Chloridoideae (Hilu, 2004). Variation in basic chromosome number, the frequency of polyploidy, and hybridization is common in grass family but there is a kind of homogeneity in the basic chromosome number in Aeluropus.

In this study, all the species were found to be diploid. Two species, A. littoralis and A. lagopoides, showed mitotic numbers $2 n=20$ that were in agreement with previous results (Murin, Chaudhri, 1970; Nagabhushana, 1980; Tarnavschi, Lungeanu, 1982; Kožuharov, Petrova, 1991). In A. macrostachyus, $2 n=20$ was also found which is the first record of the mitotic number for this species. Previously Khatoon and Ali (1993) reported the meiotic number $x=10+1 \mathrm{~B}$ for $A$. macrostachyus.

The inter-chromosome asymmetry index varied from 0.20 to 0.26 , indicating similar chromosome length of taxa. Based on this index, A. littoralis had more variation in chromosome length. Aeluropus littoralis and A. lagopoides showed more similarities in karyotype characters. The close relationship of these taxa was also confirmed in morphological and anatomical studies (Abivardi et al., 2010). Chromosomes are of the metacentric $(\mathrm{m})$ and submetacentric $(\mathrm{sm})$ types. The amount of metacentric chromosomes in the cytotypes studied suggests that the karyotype of these species shows a trend to be stable. Aeluropus macrostachyus with 3A Stebbins's symmetry class had more symmetrical chromosomes than two other species. Among species studied, A. macrostachyus had the lowest inter-chromosomal $\left(\mathrm{CV}_{\mathrm{CL}}\right)$ and intra-chromosomal asymmetry $\left(\mathrm{M}_{\mathrm{CA}}\right)$ while $A$. littoralis had the highest values of these parameters.

To have a better understanding of the variation in this genus, a cytogenetic study is suggested to consider the behaviour of the chromosomes during meiosis. There are some hybrid populations of Aeluropus species in Iran (Abivardi et al., 2010). Studying the chromosome counts of these populations is highly recommended.

\section{REFERENCES}

Abivardi F., Keshavarzi M., Assadi M., Seifali M. 2010. Numerical taxonomy of Aeluropus TRIN. (Poaceae) in Iran. Taxonomy and Biosystematics Journal 2(3): 85-102.

Avdulov N. P. 1931. Karyosystematic studies in the grass family. Bulletin of Applied Botany, Genetics and Plant Breeding (Supplement) 44: 1-352.

Baquar S. R., Saeed M. 1969. Chromosome studies and polyploidy analysis in grasses of west Pakistan I. Caryologia 22(2): 103-111. DOI: 10.1080/00087114.1969.10796328

Bor N. L. 1970. Aeluropus Trin. In: Flora Iranica. Vol. 70. K. H. Rechinger (Ed.). Graz: Akademische Druck-u Verlagsanstalt. Pp. 419-423.

de Wet J. M. J. 1987. Hybridization and polyploidy in the Poaceae. In: Grass systematics and evolution. T. R. Soderstorm, Kh. W. Hilu, C. S. Campbell, M. A. Barkworth (eds). Washington DC: Smithsonian Institution Press. Pp. 188-194.

Hilu Kh. W. 2004. Phylogenetics and chromosomal evolution in the Poaceae (grasses). Australian Journal of Botany 52(1): 13-22. DOI: 10.1071/BT03103

Hilu Kh. W., Alice L. A. 2001. A phylogeny of Chloridoideae (Poaceae) based on matK sequences. Systematic Botany 26(2): 386-405.

Keshavarzi M., Abivardi F., Assadi M. 2009. Anatomical survey of Aeluropus (Poaceae) leaves of Iran. Shahid Chamran University Journal of Science (Section B) 23: 100-116.

Khatoon S., Ali S. I. 1993. Chromosome atlas of the angiosperms of Pakistan. Karachi: Department of Botany, University of Karachi. 232 pp.

Kožuharov S. I., Petrova A. V. 1991. Chromosome numbers of Bulgarian angiosperms. Fitologija 39: 72-77.

Levan A. K., Fredga K., Sandberg A. A. 1964. Nomenclature for centromeric position in chromosomes. Hereditas 52(2): 201-220. DOI: 10.1111/j.1601-5223.1964.tb01953.x

Matevosian A. K. 1975. Materials for the karyology of Aeluropus littoralis (Gouan) Parl. Biological Journal of Armenia 28(6): 89-91.

Modarresi M., Nematzadeh G. A., Moradian F., Alavi S. 2012. Identification and cloning of the Cu/Zn superoxide dismutase gene from halophyte plant Aeluropus littoralis. Russian Journal of Genetics 48(1): 118-122. DOI: 10.1134/ S1022795411100127

Mohsenzadeh S., Malboobi M. A., Razavi K., Farrahi-Aschtiani S. 2006. Physiological and molecular responses of Aeluropus lagopoides (Poaceae) to water deficit. Environmental and Experimental Botany 56(3): 314-322. DOI: 10.1016/j.envexpbot.2005.03.008 
Moinuddin M., Vahidy A. A., Ali S. I. 1994. Chromosome counts in Arundinoideae, Chloridoideae, and Poideae (Poaceae) from Pakistan. Annals of Missouri Botanical Garden 81(4): 784-791.

Murin A., Chaudhri I. I. 1970. Gramineae. In: IOPB chromosome number reports XXVI. A. Löve. (Ed.). Taxon 19: 266.

Nagabhushana R. S. A. 1980. Gramineae. In: Chromosome number reports LXVIII. A. Löve. (Ed.). Taxon 29: 545.

Öztürk M., Altay V., Güvensen A. 2019. Sustainable use of halophytic taxa as food and fodder: An important genetic resource in Southwest Asia. In: Ecophysiology, abiotic stress responses and utilization of halophytes. M. Hasanuzzaman, K. Nahar, M. Öztürk (eds). Singapore: Springer. Pp. 235-257.

Paszko B. 2006. A critical review and a new proposal of karyotype asymmetry indices. Plant Systematics and Evolution 258: 39-48. DOI: 10.1007/s00606-005-0389-2

Peruzzi L., Eroğlu H. 2013. Karyotype asymmetry: again, how to measure and what to measure? Comparative Cytogenetics 7(1): 1-9. DOI: 10.3897/CompCytogen.v7i1.4431

POWO [2021]. Plants of the World online. Kew: Royal Botanic Gardens. URL: http://www.plantsoftheworldonline. org/ (Accessed 03 April 2021).

Shchapova A. I. 2012. Evolution of the basic chromosome number in Poaceae Barnh. Russian Journal of Genetics: Applied Research 2(3): 252-259. DOI: 10.1134/S2079059712030100

Soreng R. J., Peterson P. M., Romaschenko K., Davidse G., Teisher J. K., Clark L. G., Barberá P., Gillespie L. J., Zuloaga F. O. 2017. A worldwide phylogenetic classification of the Poaceae (Gramineae) II: An update and a comparison of two 2015 classifications. Journal of Systematics and Evolution 55(4): 259-290. DOI: 10.1111/jse.12262

Soreng R. J., Peterson P. M., Romaschenko K., Davidse G., Zuloaga F. O., Judziewicz E. J., Filgueiras T. S., Davis J. I., Morrone O. 2015. A worldwide phylogenetic classification of the Poaceae (Gramineae). Journal of Systematics and Evolution 53(2): 117-137. DOI: 10.1111/jse.12150

Stebbins G. L. 1982. Major trends of evolution in the Poaceae and their possible significance. In: Grasses and grasslands: systematics and ecology. J. R. Estes, R. J. Tyrl, J. N. Brunken (eds). Norman: University of Oklahoma Press. Pp. 3-36.

Tarnavschi I. T. 1948. Die Chromosomenzahlen der Anthophyten-Flora von Rumänien mit einem Ausblick auf das Polyploidie-Problem. Buletinul Gradinii Botanice si al Muzeului Botanic dela Universitatea din Cluj, 28 Suppl: $1-130$.

Tarnavschi I. T., Lungeanu I. 1982. Bemerkungen über einige Chromosomenzahlen wildwachsender Arten aus Rumänien. Lucr. Grad. Bot. Bucureşti 1981: 7-20.

Watson L., Macfarlane T. D., Dallwitz M. J. 1992 onwards. The grass genera of the world. Version: $15^{\text {th }}$ November 2019. URL: http://delta-intkey.com (Accessed 02 December 2020).

Zarco R. C. 1986. Anew method for estimating karyotype asymmetry. Taxon 35(3): 526-530. DOI: 10.2307/1221906 